\title{
COVID-19: assessment and forecast of the development of the residential real estate market of the Russian Federation using the housing affordability factor model
}

\author{
Tatyana Tretyachenko, Galina Pivovarova ,", and Svetlana Sogomonyan \\ Department of Commerce and Logistics, Rostov State University of Economics (RINH), Sadovaya \\ Str., 69, 344002 Rostov-on-Don, Russia
}

\begin{abstract}
The situation in the Russian real estate market can be significantly aggravated in the context of the crisis caused by the pandemic COVID-19. To understand how soon the Russian residential real estate market will be able to adapt to the new realities, it is necessary to give a forecast of the main trends that will occur in this sector in the post-viral era. The impact on the residential real estate market of the crisis caused by the widespread introduction of the quarantine regime and other restrictive measures in the framework of countering the pandemic of viral infection, the declaration of public health emergencies has not been investigated in the international and domestic literature. Since the current crisis is caused by the shock of demand and the shock of supply, which allows us to talk about it as a financial crisis with massive bankruptcy of both legal entities and individuals, the authors in their study relied on scientific works, the subject of which were the development of the real estate market in the context of the economic crisis. The main results of the study include: highlighting the characteristics of the residential real estate market that developed on the eve of the outbreak of the crisis; in conditions of shock period; its restoration and possible directions for the development of the residential real estate market in the near and medium term. In order to predict the situation in the domestic residential real estate market, a model of housing affordability ratio was applied (taking into account mortgage support). The findings of a study of the situation in the residential real estate market allowed the authors to propose a number of measures that need to be taken at the level of state authorities in the context of the "pandemic effect."
\end{abstract}

\section{Introduction}

The peculiarity of the modern stage of the development of the socio-economic system of Russia, the subsystem of which is its residential real estate market, is that the situation with COVID-19 is layered on the processes of changing technological and world economic structures, and so resonantly intensifying crisis phenomena.

${ }^{*}$ Corresponding author: gbp@list.ru 
An outbreak of pneumonia COVID-19 was first recorded in December 2019 in Chinese Wuhan. But by the spring of 2020, the virus spread around the world, which became the basis for the declaration of a pandemic by the World Health Organization. Despite all the efforts made by the world community to contain the virus, it is currently recorded in more than 200 states.

In accordance with federal legislation, in connection with the threat of the spread of a new coronavirus infection (COVID-19) in all constituent entities of the Russian Federation, with the exception of 4 regions in which restrictions were introduced already in January (Amur Region) and February 2020 (Jewish Autonomous Region, Yaroslavl Region, Republic of Buryatia), in the first half of March 2020, a high alert regime was introduced. In 43 regions of the country this situation was recognized as force majeure circumstance (force majeure) (Communication center of the Government of the Russian Federation for a situation with coronavirus) [1]. This is due to the fact that the pandemic in Russia has its own, characteristic only of it: in some regions of the country there are several cases of infection with the virus, in others, with early transmission in the community - several hundred, and in cases with uncontrolled, widespread transmission - tens of thousands of sick citizens.

Under the influence of the pandemic and related restrictive measures (total shutdown of entire sectors of the country's national economic complex, widespread introduction of the quarantine regime, etc.), entropy increased as a measure of chaoticism and a measure of uncertainty in the development of the entire economic system.

The COVID-19 blow to the sectors of the domestic economy, including the residential real estate market, turned out to be quite strong. According to the consulting company Jones Lang LaSalle in April-June 2020, the volume of transactions in the real estate market amounted to 491 million US dollars - this is the smallest indicator for the corresponding periods in the modern history of the domestic real estate market and the quarterly minimum over the past 12 years. The volume of investments in real estate in Russia in the second quarter amounted to 47 billion rubles, which is $19 \%$ lower than in the same period of 2019 (59 billion rubles). As for the residential real estate segment, the negative dynamics of sales recorded in the first half of 2020 compared to the same period in 2019 averaged $37.2 \%$ in the country, while the maximum drop in the number of transactions was registered in the North Caucasus Federal District (47.8\%), the minimum in the Far Eastern Federal District (22.6\%) (Table 1) [2].

Table 1. The number of transactions concluded in the residential real estate market before and after the crisis associated with the COVID-19 pandemic (by Federal districts).

\begin{tabular}{|c|c|c|c|}
\hline Region & $\begin{array}{c}\text { The first half of } \\
\mathbf{2 0 1 9 ,} \text { units }\end{array}$ & $\begin{array}{c}\text { The first half of } \\
\mathbf{2 0 2 0 , \text { units }}\end{array}$ & $\begin{array}{c}\text { Growth rate } \\
\text { (decrease), \% }\end{array}$ \\
\hline Central federal district & 150970,0 & 91866,0 & 60,9 \\
\hline North-Western federal district & 90941,0 & 55711,0 & 61,3 \\
\hline Southern federal district & 49085,0 & 32325,0 & 65,9 \\
\hline North Caucasus federal district & 7979,0 & 4165,0 & 52,2 \\
\hline Privolzhsky federal district & 63461,0 & 41809,0 & 65,9 \\
\hline Ural federal district & 29396,0 & 20151,0 & 68,6 \\
\hline Siberian federal district & 40959,0 & 24120,0 & 58,9 \\
\hline Far East federal district & 11673,0 & 9038,0 & 77,4 \\
\hline Russian Federation & 444464,0 & 279185,0 & 62,8 \\
\hline
\end{tabular}

The increase in the price of residential real estate in the first quarter of 2020 year compared to the 1 quarter of 2019 year amounted to the average for the Russian Federation $17.78 \%$ (the minimum price increase was registered in the North Caucasus Federal District - $0.05 \%$, and the maximum - in the North-Western Federal District - 24.2\%). The current situation in the residential real estate market is its reaction to a number of factors, 
including: the crisis of developers and homeowners, unfavorable trends in the labor market, limiting consumption in conditions of self-isolation and suspension of travel, a preferential mortgage program for buying housing in new buildings at $6.5 \%$ per annum, combined with an increase in the cost limits of acquired real estate, which earned in April 2020 and is valid until November 1, 2020. The volume of commissioning of the total area of residential premises in the whole country in the first quarter of 2020 compared to the corresponding period of 2019 decreased by almost $25 \%$. The reason for the crisis of developers and homeowners was the restrictions on movement and the access regime in the constituent entities of the Russian Federation [3], restrictions on construction work introduced in 44 regions of the country, as well as a complete halt to construction for almost a month in Moscow and the Moscow region. The index of entrepreneurial confidence during this period showed a drop of immediately $9 \%$ to critical $-24 \%$.

The weakening of restrictive measures in June, combined with fiscal measures to support households and the corporate sector, and deferred demand contributed to consumer activity. In June 2020, business activity in the Russian economy began to recover, there was a recovery in the residential real estate market. Deferred demand became a significant driver of the housing market during this period, but for a number of reasons it will not play a key role in the coming period, since the forced drop in market activity in April was largely compensated already in June 2020. Given the growth in the share of transactions in the primary housing market by an average of $31 \%$, there is every reason to believe that from July 2020, demand will be controlled primarily by record low mortgage rates and forecast long-term growth in the real estate market. However, the growth of mortgage lending in the context of a multi-year decline in population incomes (for April - June 2020, real disposable incomes of citizens decreased by $8.0 \%$ in annual terms, which, according to Rosstat, turned out to be the worst indicator since 1999) - gives us reason to talk about artificial, to some extent, stimulating demand. In addition, lowering mortgage rates may not be a sufficient measure in the current crisis, deeper and more systemic than previously observed crises [4].

From the authors' point of view, a more objective assessment and forecast of the development of the residential real estate market can be given after a more thorough analysis of the impact of all the factors of the current crisis and taking into account the situation that will develop in each region of the country in the second half of 2020, when the impact of the crisis on the housing sector will become more pronounced. Meanwhile, the importance of conducting the study at this stage is to predict the development of the residential real estate market of the Russian Federation in the short term in order to make the necessary managerial decisions on the part of the state, establish the rules of the game for the medium term, adequate for the era of ontological fault between chaos and order, reinforced by the situation with COVID-19.

The authors in their work consider the economic consequences of the pandemic COVID-19 not only in the whole country, but also in terms of macroregions (federal districts) and regions, taking into account how this event in the conditions of significant uneven levels of economic development of the Russian regions and fluctuations in the dynamics of incomes of the population (according to the Analytical Center under the Government of the Russian Federation, the gap in average per capita income between regions with a maximum and minimum per capita income remains stable compared to previous years and amounts to 5.1 times) may affect regional economic activity: reduced effective supply of resources and behavioural changes in perceptions of economic factors.

The pandemic period is COVID-19 fraught with constant situations of uncertainty. The population of the country, like the world, does not have an accurate idea of what will happen in its life in the near future, as a result of which many people have fear, confusion, oppression by uncertainty in the ability to continue to work and have a stable income. This 
uncertainty in the future leads to changes in the residential real estate market, uncertainty in its development in the future.

\section{Materials and Methods}

Analyzing the state of research in the field of the relationship between real estate markets and economic stability in Russia, we observe a certain lack of research aimed at understanding and studying the systemic relationship between the stability of the economic system and the dynamics and level of development of the real estate market. According to the authors, a small number of studies in this area are determined by the short time lag of the domestic real estate market, a rapid change in the economic system, determined by technological changes, numerous changes by the banking regulator of the regulatory framework, Since the Russian Central Bank implements risk management tools that are usually associated with real estate markets, it reserves the right, for example, to consider real estate assets used as collateral for mortgages and other types of loans). In addition, there are certain features of the Russian economy, financial industry and real estate market that are atypical for more developed economies and that potentially increase the need for this study.

The uneven development of local real estate markets throughout Russia and, as a result, the concentration of the most progressive technologies and competencies of real estate management and its valuations within the most developed (for example, Moscow, St. Petersburg are at the forefront of this process, and regional markets are far behind them). This, in turn, makes the development of relatively universal system tools for local real estate markets, which are considered "narrow" (i.e. characterized by extremely limited demand, level of development and available transactional data, as well as increased information asymmetry), especially a difficult task.

The impact of pandemics or public health emergencies on housing markets, as mentioned above, is an unexplored topic. Studies specifically looking at the housing market response to public health emergencies, units. Grace Wong's researches, Argiroudis and Siokis, Nikola, etc. concern them [5,6,7].

In 2008, Wong investigated how housing markets respond to extreme events, such as the severe acute respiratory syndrome (SARS) epidemic in Hong Kong in 2003. A panel dataset on large-scale housing complexes is used to use transverse variations in torso distribution to assess the impact of disease on real estate prices and sales. Wong concludes that the average price decreases by $1-3 \%$ if the property is directly affected by SARS, and by $1.6 \%$ for all real estate as a result of an outbreak of the disease. With regard to results, he also stressed that the absence of excessive price responses was likely due to the characteristics of the housing market.

In 2019, Argyroudis and Siokis investigated the impact of the subprime credit crisis on the Hong Kong real estate market and only slightly identified periods when certain events, such as the SARS epidemic, influenced the main dynamic structure of the real estate market.

In 2020, Nicola et al. summarized the socio-economic consequences of COVID-19 for certain aspects of the world economy. Again, in 2020, the main findings of the Zillow [8] economic study on the SARS epidemic in Hong Kong in 2003 are: $1.75 \%$ - annual loss of gross domestic product (GDP) or 5.1\% - monthly loss at the peak, 1.3\% - unemployment growth, statistically insignificant drop in house prices by $1.9 \%$, recording a drop in transactions by an average of 33\% during the entire pandemic. Zillow's economic research considers its GDP model, unemployment rate, residential real estate prices and real estate transactions as inputs. 
In the work of Razgulin A. "The global financial crisis and its impact on the state of the real estate market" [9], the results of a study of the historical impact of economic crises on the state of the real estate market are presented, the prospects for its development are analyzed. According to A. Razgulin, the result of rising real estate prices and construction volumes is the formation of a "bubble" in the market of mortgages and derivative securities. The study of Ushakova N. and Khurmatulina N. examines how the crisis affects the real estate market in Russia [10]. Changes in Russian legislation directly affect the functioning of organizations and socio-economic life in general. Busov V. 's study [11] outlines the main forms and methods of financing the real estate market, which contribute to increasing the availability of housing for the population, creating jobs in construction and related industries.

The need to conduct crisis management not only in the commercial real estate segment, but also in the housing sector during the economic crisis is examined in his work by Zaychenko K., the activities of companies providing services for crisis management of commercial real estate are aimed at preventing and mitigating the consequences of the crisis [12].

In his research, Lemeshko D. [13] considered the need to improve investment risk management technology in conditions of instability of the real estate market and their adaptation to the realities of the post-crisis economy.

The study of Krylov E. and Bartholomeev V. [14] analyzed the trends in real estate market changes during the financial crisis of 2014-2015, from the point of view of the authors it is possible to predict the market situation only for the short term, and about expectations of length per year - only in the context of various scenarios of events depending on general trends in politics and economics.

The authors also examined studies related to the impact of terrorist acts and natural disasters on real estate prices $[15,16,17,18,19,20,21,22]$, however, the authors' proposed approaches and tools cannot be adapted to a domestic residential real estate market model aimed at addressing the consequences of a public health pandemic.

The analysis of the works of foreign and domestic scientists, conducted by the authors, illustrates the researchers' deep understanding of the most important characteristics of real estate markets, which must be taken into account when studying the effects of the crisis on the market - these are the relative illiquidity of real estate assets, low transparency of real estate transaction data, dependence on significant negative external effects (unemployment and mobility of the population, their monetary income, the state of the construction industry, banking sector game rules).

The authors in their study use official data from state bodies, the Bank of Russia, the results of various national surveys on the current scenario COVID-19 to implement a model of housing affordability coefficient (taking into account mortgage support), focused on the behavioral effects of homeowners in the residential real estate market.

The impact on residential real estate markets of pandemics or public health emergencies in the works of domestic and foreign authors, as already mentioned above, has not been investigated. The studies of a number of foreign authors concerning the impact on the residential real estate market of the consequences of the introduction of emergencies due to terrorist acts and natural disasters cannot in our opinion serve as an analogy of the current situation. The impact of the current crisis is specific, it is associated with the actual shutdown for several months of work of almost all economic entities, which only exacerbates the systemic weakness of the economy and reveals the lack of points of support for long-term development. We used for analysis and forecasting the work of scientists who studied the impact of financial crises on the domestic real estate market, a brief overview of which is given in the corresponding section of the study. 
The results of the study, from the history of the development of the real estate market and macroeconomic indicators of the Russian Federation to the emergency situation COVID-19, the current COVID-19 scenario is presented (with an emphasis on employment, personal and family income, and real estate dynamics). An assessment of the patterns of market behavior in the whole country and in the context of its federal districts was carried out. To predict possible changes in the medium term of the dynamics of residential real estate, an economic model of housing affordability ratio was applied taking into account mortgage support.

The authors in their study use the results of various nationwide surveys on the current COVID-19 scenario to implement a regressive model focused on property values and behavioral effects of homeowners.

The impact on residential real estate markets of pandemics or public health emergencies has not been investigated in the works of domestic and foreign authors. The studies of a number of foreign authors concerning the impact on the residential real estate market of the consequences of the introduction of emergencies due to terrorist acts and natural disasters cannot in our opinion serve as an analogy of the current situation. The impact of the current crisis is specific, it is associated with the actual shutdown for several months of work of almost all economic entities, which only exacerbates the systemic weakness of the economy and reveals the lack of points of support for long-term development. We used for analysis and forecasting the work of scientists who studied the impact of financial crises on the domestic real estate market, a brief overview of which is given in the corresponding section of the study.

The results of the study, from the history of the development of the real estate market and macroeconomic indicators of the Russian Federation to the emergency situation COVID-19, the current COVID-19 scenario is presented (with an emphasis on employment, personal and family income, and real estate dynamics). The market behavior patterns were evaluated on the basis of the model of coefficients of joint dynamics in the whole country and in the context of its federal districts. To predict possible changes in the medium term of the dynamics of residential real estate, an economic model of housing affordability ratio was applied taking into account mortgage support.

\section{Results and Discussion}

According to the international rating agency Standard \& Poor's Global Ratings [23], despite the fact that in most of the world, including Russia, the peak of the pandemic is either near or past, COVID-19 will remain a threat until at least the end of 2021. The COVID-19 strike was quite strong (for example, in the housing sector, a number of indicators indicate that during the period of strict restrictive measures, when in 44 regions there were restrictions on construction work, and in two - Moscow and the Moscow Region - construction was completely stopped for almost a month, according to Rosstat for the first six months of 2020, the volume of input of the total area of residential premises compared to the corresponding period of 2019 decreased by almost 25\%, the Index of entrepreneurial confidence showed a drop immediately by $9 \%$ to critical $-24 \%$ [24]. The situation in the boomerang housing sector has affected the state of the residential real estate market. In the first quarter of 2020, 147 thousand contracts for participation in shared construction were registered, which is $27 \%$ less compared to the same period in 2019 . Over the six months of 2020 , the drop in the number of contracts concluded has already amounted to $37.2 \%$ compared to the first half of 2019 [2].

The current pandemic is a crisis caused by the introduction of sanitary force majeure, which in its scale exceeds the Great Recession of the 2008-2009 years, and in its depth is 
comparable to the losses of the economy of Europe and the United States during the Second World War or the Great Depression of the 30s of the last century [25].

In this regard, it is possible to draw a historical analogy that will identify possible risks, understand what will happen to the housing sector in the context of the growing crisis, simulate the conditions for the development of the situation, which will avoid a sharp drop in the construction of residential real estate and the stagnation of the development sector.

\subsection{Construction and market research real estate in times of crisis 1998, 2008 and 2014}

Before drawing an analogy of the current situation with the crises of 1998, 2008. and 2014, to make forecasts of the development of the residential real estate market, we note that unlike previous shocks, the 2020 crisis is not accompanied by an "overheating" of the economy and the imbalance of the ruble exchange rate, it does not contain risks caused by a cyclical economic contraction, and on the dynamics of the domestic economic system except quarantine measures (declaration at the state level for all economic entities with a non-working period of working days in April and May 2020 and suspension of the work of enterprises of a number of industries from the end of March 2020) changes in hydrocarbon prices in the world market have a significant impact as always. At the same time, it is important to remember that the rate of recovery of all sectors of the Russian economy, including those studied in this article, largely depends on the rate of decline in prices and volumes of Russian oil and gas exports, since there is a high dependence of domestic demand and investment activity on the income from oil and gas exports entering the country.

Over the past two decades, the sharp drop in oil prices in the world market has repeatedly had a serious negative impact on the situation in the Russian economy (crises of $1998,2008,2014)$, which reflected on the state of the residential real estate market.

The technical default of August 1998, when the Russian government introduced a moratorium on the repayment of external debts by domestic banks and the forced restructuring of debts on state securities, was the first serious blow to the Russian housing market.

During this period, the development market was only nascent, there were practically no new buildings, since developers could not get project financing, and the mortgage institution had not yet been formed (the Federal Law "On Mortgages (Real Estate Collateral)" was signed by the President of Russia and published on July 16, 1998), so the secondary housing market took the main hit [26].

The crisis led to an outflow of expats, who mainly rented apartments in Moscow, which prompted a drop in prices and demand and led to a halt in all transactions in the secondary housing market for a certain period. In addition, the default led to a temporary correction of the market, when house prices fell by $30 \%$ (from $\$ 1,000$ per 1 square meters. $m$ to $\$ 700$ per 1 square meters. $\mathrm{m}$, for comparison: at a historical maximum - before the 2008 crisis, house prices amounted to about $\$ 6,200$ per 1 square meters. $\mathrm{m}$ ). The residential real estate market recovered only by the age of 2002-2003. The crisis spurred the development of the primary real estate market. Active mass residential development began.

The 2008 crisis, like the 1998 crisis, was the result, including the internal problems of the Russian economy, although the trigger was the mortgage crisis in the United States, which crossed the borders of national economies and covered the entire world economy, including Russia. The price per barrel of Urals crude oil fell from $\$ 132.1$ to $\$ 39.1$, the average monthly rate of industrial decline in the domestic economy fell to $3.6 \%$, which, in terms of theory, characterizes the acute and deep phase of the recession, and Russia's external debt reached $30 \%$ of GDP. During this period, the growth rate of incomes of the 
population has undergone a significant decrease relative to previous periods. There was a tightening of bank requirements for borrowers, which led to a slowdown in mortgage development. In addition, it was planned to commission 66.0 million square meters in 2008 , but 64.1 million square meters or $97.1 \%$ were actually commissioned. In $2009,59.8$ million square meters were commissioned, which is $6.71 \%$ less than in 2008 .

Before the 2008 crisis, there was a sharp increase in housing prices (in 2006 alone, the increase reached $48 \%$, Fig. 1).

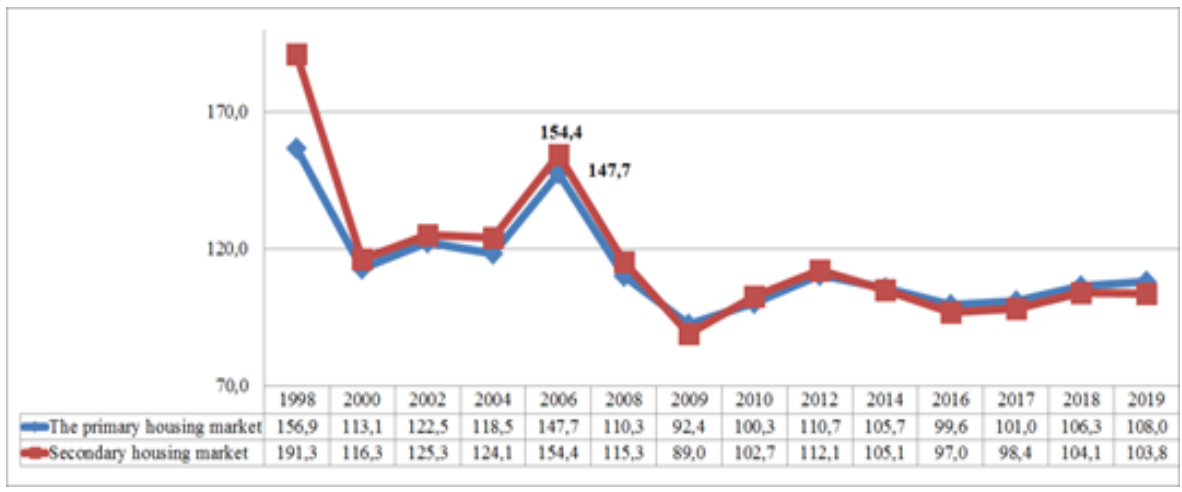

Fig. 1. Price indices for apartments in Russia in the years 2000-2019, \% (27. Center for SocioEconomic Research, Rosstat, 2020) [27, 28].

The reason was an increase in population demand for residential real estate in both the primary and secondary markets, associated with an increase in oil rents in the economy (and an increase in the well-being of the population) in conditions of insufficient supply in the market.

All these factors could not but affect the development of the real estate market. The number of sales transactions in 2009 compared to the pre-crisis year 2007 according to the Federal Service for State Registration, Cadastre and Cartography decreased by $16.5 \%$ (in 20072,326 million sales transactions between individuals took place, and in 2009 only 1,943 million contracts for the sale of housing were concluded).

By the beginning of the 2008 crisis, the real estate market had changed a lot. Over the past decade after the crisis of 1998, the housing market has been supplemented by a new sector - houses under construction, and it was this sector that suffered the main blow in the crisis of 2008. All sources of financing for development projects were significantly affected.

The relatively rapid recovery, which was not observed after the collapse of 1998, was also a distinctive feature of the 2008 crisis. Already in 2011, the residential real estate market began to operate normally. Despite the drop in housing commissioning in 2010, when only 58.4 million square meters were commissioned, which is $2.34 \%$ less than in 2009 , during this period the growth of mortgage loans amounted to 10 times or more.

Another crisis faced by the Russian economy (commodity dependence, low domestic consumption, lack of available sources of financing, falling oil prices) erupted in 2014, it became a new stage of the recession and the continuation of the 2008 crisis. However, unlike the 2008 crisis, it was protracted. Events in Ukraine and the accompanying foreign policy crisis played a special role in weakening the Russian economy. Some economists believe that the new recession was a direct continuation of the 2008 crisis. Its result was a decline in GDP growth, which took place throughout the year, and for the first time since 2009 moved into the field of negative values. During this period, the ruble lost $70 \%$ of its value, and the refinancing rate established by the Central Bank of Russia reached $17 \%$, the investment process in the economy almost stopped. 
The crisis of 2014 was different, more systemic, during this period the real estate market was influenced by two trends: a drop in solvent demand and an increase in construction costs. The real estate market responded to the next round of the crisis in the same way as in previous years: a decrease in demand, a decrease in the pace of construction, a decrease in ruble prices, which, taking into account the fall in living standards, actually increased for most buyers. A new phenomenon was the growing importance of mortgage lending, which actually stretched housing construction in a recession.

The negative impact of the crisis on the real estate market was manifested in the fact that, starting in 2016, there has been a decrease in the volume of commissioning of housing: in 2016 - 80.2 million square meters. $\mathrm{m}$, in 2017 - 78.6 million square meters. $\mathrm{m}, 2018$ $75.7 \mathrm{mln}$. sq. $\mathrm{m}$. The number of mortgage transactions is reduced: if in 2014 the share of transactions reached $45 \%$, then in 2015 their share was about $20-25 \%$. At the beginning of the summer of 2015 , approximately $40-50 \%$ of residential real estate in the secondary market was sold at a discount, and in the fall the share of such objects reached $90 \%$, and the average discount was 7\% [29].

The turning point in the residential real estate market was 2019, in the middle of which the social problem of "deceived equity holders" was especially acute, which was strengthened by the norms of the Federal Law of \$3-214, which allowed developers to use the funds of equity holders for other purposes.

To resolve this issue, the said law was amended, which fully entered into force in July 2019. The changes made it possible to solve the problem of "deceived equity holders," but at the same time led to an increase in the cost of construction, which further aggravated the problem of housing affordability for Russian citizens (many developers increased the price of housing to maintain the profit rate. The increase in the price of 1 square meters. $\mathrm{m}$ of residential real estate in the primary market amounted to $3.62 \%$, which led to a drop in sales volumes by $1.69 \%$.

\subsection{The situation in the Russian residential real estate market on the eve of the introduction of quarantine restrictions}

The primary residential real estate market in Russia in 2019 was formed under the influence of a significant regulatory change in the construction industry - the introduction of a model for financing projects using escrow accounts, which accumulate funds from citizens participating in shared housing construction. The use of the project financing and banking support mechanism made it possible to increase the transparency of the construction industry, but at the same time had a significant impact on the prices and supply of housing.

At the end of 2019, housing commissioning in Russia amounted to 79.4 million square meters. $\mathrm{m}$, exceeding the 2018 value by $4.9 \%$. The increase was largely due to the dynamics of the introduction in the first half of the year, on the eve of the entry into force of the new rules for shared construction (Fig. 2).

In the last months of 2019, there was a slowdown in housing construction, which led to a reduction in the introduced housing areas since October and in December the annual dynamics of commissioning became negative. 


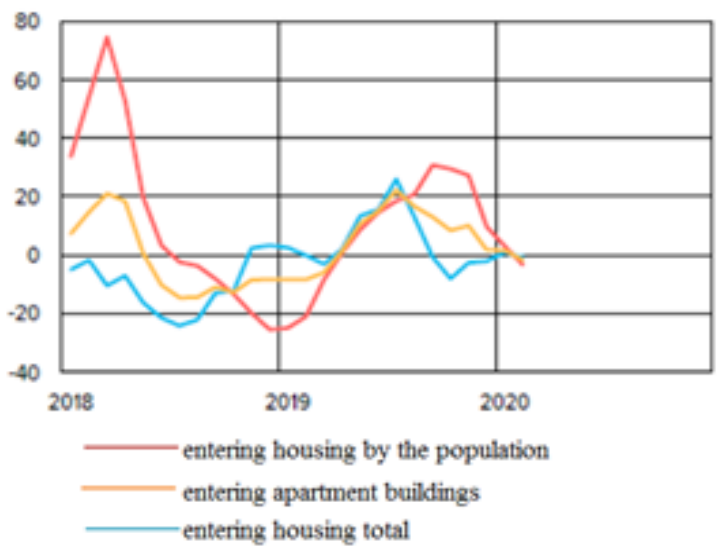

Fig. 2. Housing commissioning, for a rolling quarter, year/year, \% (Rosstat, Bank of Russia, 2020) $[28,30]$.

The growth in the supply of new housing in the real estate market in 2019 was mainly due to the temporary factor - the transition of the construction industry to the rules of project financing and an increase in construction volumes on the eve of this transition.

By the end of 2019, the effect of this factor was largely exhausted, the dynamics of the introduction slowed down. At the same time, the decline in mortgage rates in the second half of the year and a slight acceleration in population income growth have not yet affected the dynamics of demand for housing and real estate market indicators.

The decrease in mortgage rates observed in the second half of 2019 - early 2020, according to expert estimates, could have a positive impact on the dynamics of the primary residential real estate market. The possible increase in housing demand and construction volumes was indicated by the expectations of developers participating in the monitoring of enterprises conducted by the Bank of Russia, which were improving by the end of 2019 [30].

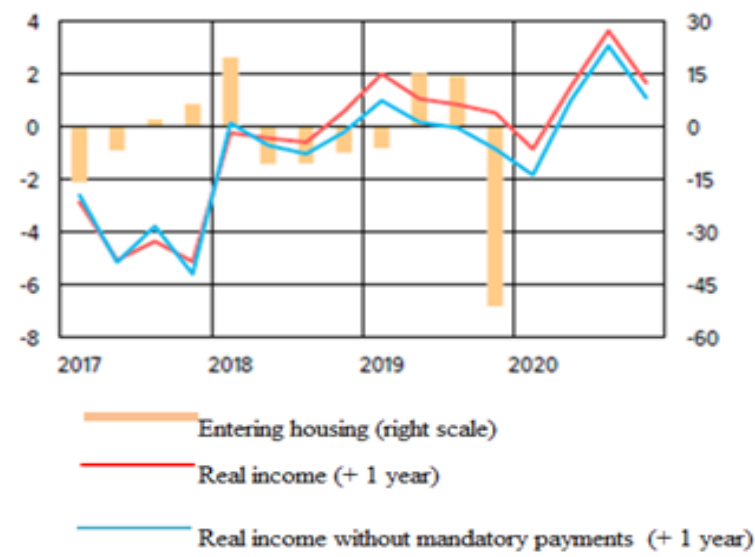

Fig. 3. Real incomes and housing starts in Russia, \% increase over the previous year (Rosstat, Bank of Russia, 2020) [28, 30].

Housing demand factors in 2019 were as follows. In the first quarter of 2019, against the background of accelerating inflation, a decrease in real monetary incomes of the 
population was observed. In the 2nd quarter of 2019, the monetary incomes of the population resumed their growth (Fig. 3), which made it possible to predict support for housing demand on the 2020 horizon in the whole country.

In the regional context, the relationship between changes in real incomes and the dynamics of housing demand varies considerably. According to Bank of Russia estimates, in 2019 it was most significantly traced for regions with an average per capita income close to the Russian average. In low-income regions, housing remained difficult to access (the cost of 1 square meters. meters of housing in 2018 was $125 \%$ of the average per capita monthly income [31]. Throughout 2019, the annual growth rate of population spending on the purchase of housing was mainly in the negative zone (Fig. 4). This was due to a significant annual growth rate in real estate spending in 2018 , which was about $30 \%$, as well as a more restrained increase in wages.

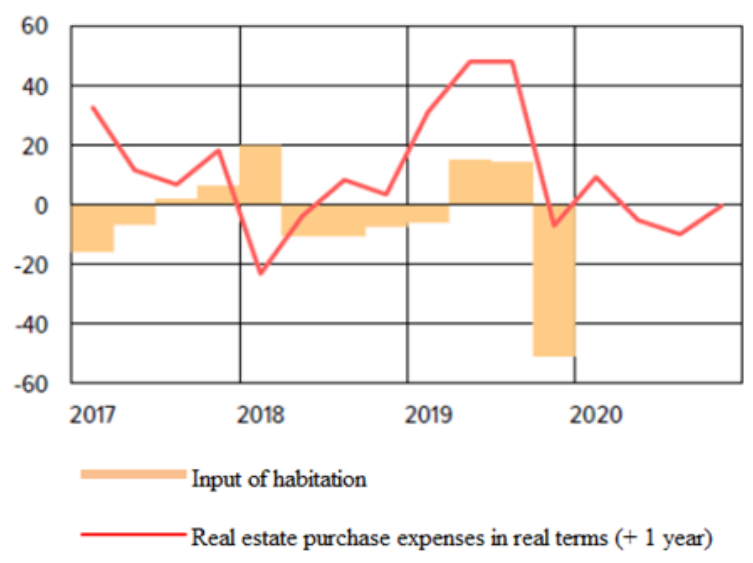

Fig. 4. Real incomes and housing starts in Russia, \% increase over the previous year (Rosstat, Bank of Russia, 2020) [28, 30].

Given that the dynamics of real estate spending in 2019 corresponded with the dynamics of the supply of new housing with a lag of about 1 year, it was predicted that in 2020 the annual growth rate of demand for housing will be formed near zero [30]. A higher rate of growth in housing demand could occur only in the context of a higher rate of growth in wages and federal budget expenditures as part of various measures to support the housing market.

According to Bank of Russia estimates, in 2019, the availability of mortgage lending increased, which supported housing demand, but only in those regions of the country where the average cost of housing was lower than the Russian average. At the same time, in the first half of 2019, against the background of a temporary increase in mortgage rates, the debt burden of the population on loans gradually increased. Under these conditions, as well as under the influence of a number of regulatory measures, the growth of the mortgage loan portfolio as a whole in Russia steadily decreased and by the end of 2019 fell to the level of the end of 2017.

House prices in the second half of 2019 , both in the primary and secondary markets, showed growth (Fig. 5). 


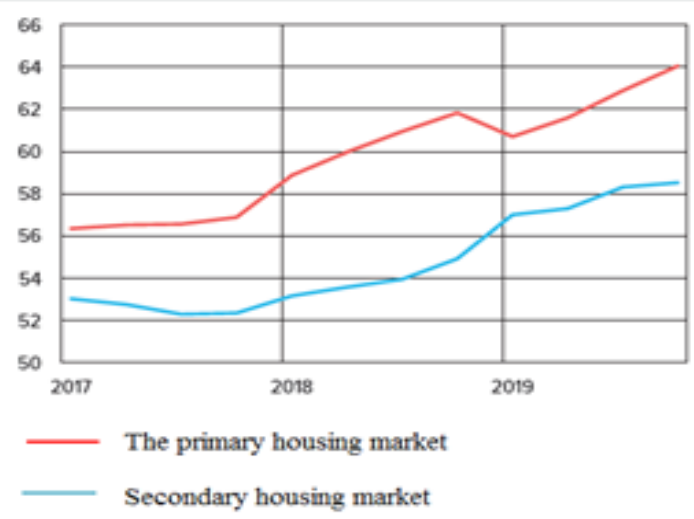

Fig. 5. Price dynamics in the primary market And secondary housing markets in Russia, thousand rubles per 1 sq. $\mathrm{m}$, for all types of apartments (Rosstat, Bank of Russia, 2020) [28, 30].

Prices for new buildings continued to rise faster than prices in the secondary market, and their growth rate increased in the second half of 2019, while in the secondary market on the contrary, it slowed down.

The higher rate of price growth in the primary market is due to the continued, albeit restrained, gradual transfer of the developer's costs associated with the transition to project financing to the price of housing. In addition, prices for new buildings were influenced by an increase in the supply of new apartments, the construction of which was started in 2018 on the eve of the transition to project financing. As the level of readiness increased, the price of these apartments increased. As well as growth in total sales, the share of apartments with decoration, the prices of which are higher. The impact on price increases of demand dynamics was negligible. The slowing dynamics of the number of mortgage loans issued confirms the conclusion that demand has a limited impact on the growth of housing prices. In the regional context, according to the results of 2019, an increase in housing prices in the primary market was observed in 72 regions out of 81 where Rosstat monitored average prices [30]. A significant increase in prices during this period was observed in Moscow, the average prices in the primary housing real estate market of which increased by $18 \%$, exceeding 200 thousand rubles. per 1 square meters. m (average Russian price per 1 square meters. $\mathrm{m} 64$ thousand rubles). Most of the regions where housing prices decreased were the regions of the North Caucasus and Southern Federal Districts and where such dynamics are due to weak demand for housing amid low incomes and migration outflows of the population.

According to a study conducted by PricewaterhouseCoopers - the increase in prices of concluded transactions for the sale of residential real estate in the medium term, taking into account project financing factors, the level of solvency of the population and the level of competition between projects, was predicted in the range of $5-7 \%$ (40\% of respondents) or $7-10 \%$ ( $32 \%$ of respondents). $29 \%$ of respondents believed that there would be no increase in the prices of transactions due to a possible decrease in demand for residential real estate [32].

\subsection{Analysis of the impact of COVID-19 on the Russian residential real estate market}

The adverse epidemiological environment associated with the spread of coronavirus infection has had a negative impact on all areas of business. The real estate market also faced new difficulties. 
Restrictions imposed on the activities of organizations have significantly reduced the attendance of retail facilities. The closure of borders with other countries, the cancellation of international flights and restrictions on domestic tourism deprived hotels of guests. Forced self-isolation contributed to a decrease in housing sales, and the suspension of construction activities led to a postponement of the commissioning of facilities. Thus, measures taken to combat COVID-19 led to a decrease in consumer activity of the population and, as a result, significant financial losses of companies.

Meanwhile, experts predicted the onset of another global cyclical crisis in 2014, pointing out as its main reason the recapitalization of existing markets and increased monopolization of the economic space, but the cause of the global economic crisis in 2020 was the spread of coronavirus infection.

In the face of falling oil prices (it is predicted that in the near future the average annual oil prices will stop at "\$25" per barrel and even lower), the level of gross domestic product (it is forecast to fall by 10-20\%) there is a potential danger for all sectors of the Russian economy. For Russia, 2020 may be the worst year since 1992, when GDP fell by $14.5 \%$ according to the World Bank (during the 1998 crisis, Russia's GDP fell by 5.3\%, and in 2009 - by $8 \%$ ) [33].

A number of economists express the opinion that the consequences of quarantine restrictions imposed on the economy are close in nature to the situation of the early $90 \mathrm{~s}$ of the last century, when during the transition of the country from the administrative-planned system of the economy to the market conditions of the economy there was a break in the existing ties. When predicting the consequences of the restrictions imposed according to Blanchard and Kremer, it is necessary to take into account the complexity of the production chain, since the depth and duration of the decline largely depends on the complexity of such a chain. Production chains in sectors affected by significant "pandemic" restrictions are mostly simple and short (the duration is determined exclusively by the time limits of the restrictions imposed: March - June 2020), which suggests their recovery quite quickly. According to a number of scientists, the main negative effect of today's crisis will be in 2020 , and from next year, without reference to the price of oil, the adaptation of the economy and economic entities to the current conditions will begin [33]. According to forecasts of the Ministry of Economic Development, economic recovery may begin in 2021, but it will depend more on the epidemiological situation, which may be aggravated by the second wave of the pandemic. Against this background, there is a danger of a protracted exit from the global recession.

The current situation does not allow making any forecasts for the restoration of the residential real estate market without reservation. There remains a mood of general uncertainty in society, which is a deterrent to decision-making even for a financially stable audience, not to mention the fact that spring events hit the personal budget of a third of the country's population. Based on the results of a sample survey of consumer expectations of the population for the II quarter of 2020 year by Rosstat, the Consumer Confidence Index, reflecting the total consumer expectations of the population, in the 2 quarter of 2020 year reached the minimum value for the last 4 years - the index decreased by $19 \%$ compared to the previous quarter and amounted to $-30 \%$. This means that the population, assessing what happened and expected personal financial situation, the economic situation in the country and the favorable conditions for making large purchases, does not express positive sentiments regarding the expected consumption. Due to these circumstances, the framework for the transformation of the real estate market in the post-pandemic period will be determined primarily by the financial capabilities of buyers (their income taking into account mortgage lending) and housing prices.

The pandemic of new coronavirus infection (COVID-19) and the quarantine measures introduced to contain it have had a significant impact on consumer demand, as well as on 
the social situation of the population. The main blow to the real disposable incomes of the country's population came in the II quarter of 2020, most of which coincided with the active phase of introducing restrictive measures to curb the spread of the disease.

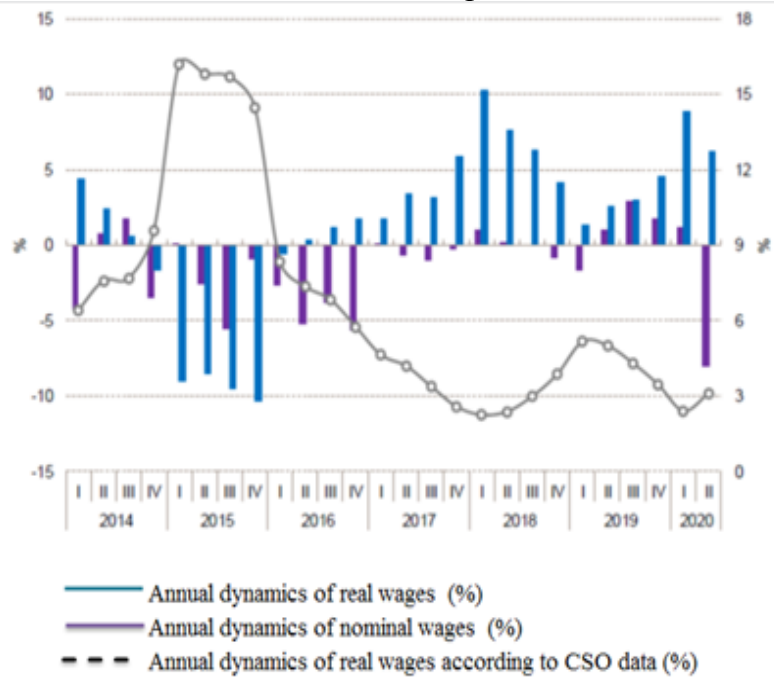

Fig. 6. Dynamics of the average monthly nominal and real accrued wages of employees of organizations (Center for Socio-Economic Research, Rosstat, 2020) [27, 28].

In April - June 2020, real disposable incomes of citizens decreased by $8.0 \%$ in annual terms, which, according to Rosstat, turned out to be the worst indicator since 1999 (Fig. 6).

According to Rosstat, the number of poor was in January-March 2020. 18.6 million or 12.6 per cent of the total population. Compared to the same period in 2019, the proportion of people with incomes below the subsistence minimum decreased by $1.7 \%$. Such a decrease in the number of poor, according to the authors, is largely due to the fact that, according to Rosstat estimates, the cost of the minimum necessary set of goods and services for life has not changed for the year, the cost of living adopted by Rosstat to calculate poverty in the first quarter of 2020 year amounted to $10,843.0$ rubles per month, that is, + $0.8 \%$ per annum. The conclusion, to put it mildly, is controversial, given that inflation at the end of March 2020 was $2.5 \%$ per annum, and food inflation $-2.2 \%$ per annum.

The unemployment rate (ratio of the number of unemployed to the labor force) in June 2020 was $6.2 \%$ (Fig. 7).

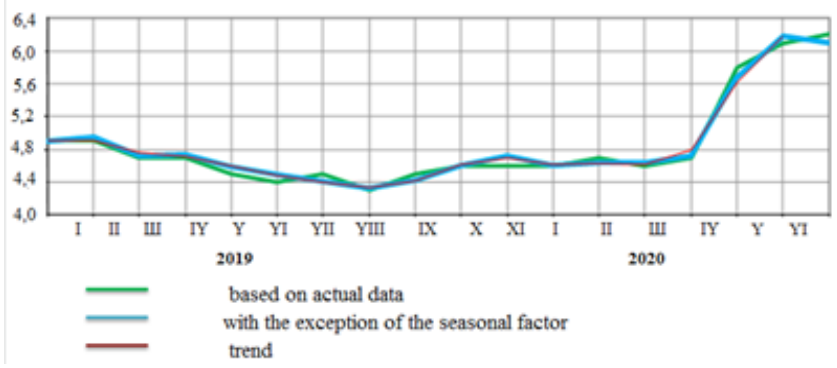

Fig. 7. The dynamics of the unemployment rate of the country's population aged 15 years and older, in $\%$ of the labor force (Rosstat, 2020) [28].

The reduction of salaries and the loss of work for many citizens affected the reduction of the solvency of the population. 
In the face of falling incomes and declining employment caused by the coronavirus pandemic COVID-19 and worsening global economic and political conflicts, households burdened with credit obligations were at particular risk. The rapid increase in retail lending (consumer and housing) in 2017-2019. was a matter of concern and close attention from the government and the financial regulator. A long period of stagnation of real monetary incomes of the population, against the background of declining subjective fears about the future financial situation of families, contributed to the maintenance of consistently high demand for consumer loans. Various mortgage development programs have also stimulated the growth of demand in this market. Consumer loans have become widespread among Russian households. In the first quarter of $2020,42 \%-43 \%$ of families reported that they were paying a loan [30]. The total amount of credit debt of resident individuals in the banking system of the Russian Federation at the end of the first quarter of 2020 exceeded 18 trillion rubles. Therefore, in the packages of measures to support the population in connection with the introduction of the self-isolation regime, a special and significant place was given to assistance to the population burdened with loans. The Law on Credit Holidays was adopted, which guaranteed the postponement of payments on loans and loans for up to six months if the borrower was in a difficult life situation and faced a decrease in income by $30 \%$ or more. According to this law, credit holidays are provided to individuals if the debt does not exceed 100 thousand rubles on credit cards, 250 thousand rubles on consumer credit, as well as 4.5 million rubles on mortgages in Moscow, 3 million rubles in the Moscow region, St. Petersburg and the regions of the Far Eastern Federal District, up to 2 million rubles in other regions of the country.

The decline in real disposable cash incomes of the population and the transition of most households from a consumer model of behavior to a savings one, which can lead to a narrowing of the residential real estate market. According to Rosstat, already in May 2020, the volume of input of the total area of residential premises compared to the corresponding period of 2019 fell by almost $25 \%$. Given the fact that, if there is a favorable scenario and the start of recovery growth will occur in the III-IV quarters of this year, the annual losses of housing construction in 2020 will amount to about $10 \%$. It is also necessary to take into account the fact that $32.9 \%$ of unprofitable organizations of their total number functioned in construction in January-April 2020, some of them, most likely, have a high level of lending and a significant amount of construction in progress. The volume of unfinished construction of bankrupt organizations is currently estimated by experts at 10 million square meters. $\mathrm{m}$ and this will not allow us to consider the departure of such organizations from the construction market as a mechanism of "creative destruction." The increase in the volume of construction in progress, for the completion of which, according to experts, more than 500 billion rubles are required, especially for organizations working without escrow accounts, can cause a negative reaction from home buyers, since in such a situation they acquire the status of deceived equity holders. The current situation in the construction industry may negatively affect the volume of housing commissioning and, accordingly, the volume of new buildings proposed for sale, which does not contribute to the restoration of the residential real estate market and sales growth.

Real estate prices are an indicator of the state of the real estate market, we will consider the dynamics of price changes in the primary and secondary housing markets in the first half of 2020 (Fig. 8) and evaluate their prospects by the end of this year. 


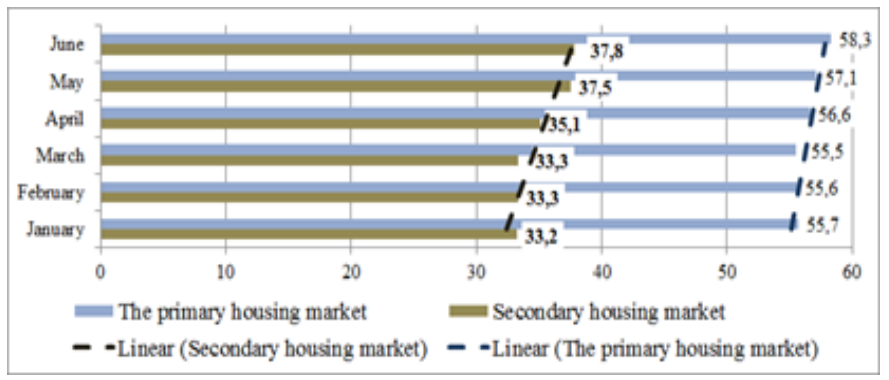

Fig. 8. Dynamics of housing prices in the primary and secondary residential real estate market, thousand rubles per 1 square meters. m (Rosstat, 2020) [28].

The depreciation of the ruble, and the proposals made by the head of state to increase the tax rate on income going abroad from $2 \%$ to $15 \%$, stimulated the growth of demand in the market of new buildings in late March and early April 2020. However, the restrictive measures imposed on April 13, 2020 related to COVID-19 led to a halt in construction work, which led to a narrowing of the supply of new buildings, but also made it impossible for potential buyers to view apartments.

The online sales system organized by developers did not solve the problem of reducing sales in the primary housing market. Expectations related to the revival of sales of residential real estate after the lifting of restrictions did not materialize. Most buyers who prefer the traditional offline procedure for buying housing did not reach the offices of developers. For example, in Moscow, the number of transactions with primary real estate in May fell by $20 \%$ compared to April.

The secondary housing market was in a worse situation than the primary market. Citizens were on self-isolation, which did not give them the opportunity to see a real estate object for purchase. The temporary closure of the Multifunctional Centers made it impossible to register a sale on the residential real estate market. As a result, the secondary housing market "completely measured." The anti-crisis measures proposed by the Russian government in the form of a preferential mortgage at $6.5 \%$ for the purchase of housing in new buildings reoriented demand from secondary housing to the segment of new buildings, since the weighted average mortgage rate for the secondary housing market is $8.32 \%$. The existing preferential mortgage in the secondary housing market, accessible to a limited number of families: families with children and children with disabilities, together with the observed dynamics of real estate prices by months, when prices for primary housing are lower than for secondary housing (especially in Moscow), exacerbates existing problems and pushes the buyer's demand for the segment of new buildings.

A decrease in the purchasing power of the population, hype demand before selfisolation and unfavorable conditions compared to the primary housing market, can lead to stagnation in the secondary market and a decrease in the price of offers. At the end of 2020, the expected price reduction in the secondary housing market can be estimated at $15 \%$ by the beginning of the year [32].

For the primary and secondary housing market, there are common reasons that may affect the further development of the situation. Thus, the next decrease in the key rate by the Central Bank of Russia to $4.25 \%$ will be followed by a decrease in the interest rate on deposits by commercial banks and, as a result, a decrease in the motivation of citizens to place free funds on bank deposit accounts. Federal Law of March 1, 2020 No. 35-Ф3 amended the legislative acts of the Russian Federation on issues related to the disposal of maternity (family) capital. The amount of maternity (family) capital has been increased, new possibilities for using these funds have been fixed, and the duration of the maternity (family) capital program has been extended. Since 2021, the country has introduced the 
Law on a $13 \%$ tax on income from bank deposits and investments in securities exceeding 1 million rubles. In such a situation, the free financial resources of the population of the country are highly likely to invest not on a deposit, but on real estate, since the purchase of housing is considered as an instrument of insurance against the crisis. Based on Rosstat data on the distribution of households that plan to buy housing, and data from a survey of the Center for Socio-Economic Research on additional population savings when purchasing housing against the backdrop of the 2020 crisis, about 410 thousand households plan to buy housing in apartment buildings and 350 thousand in individual housing construction. Taking into account the average area of apartments of 67 square meters. $m$ and individual housing construction of 132 square meters. $\mathrm{m}$, the demand for housing in 2020 in apartment buildings can be at the level of 28 million square meters. $\mathrm{m}$, in individual construction - 46 million square meters. $\mathrm{m}[27,28]$.

The package of anti-crisis measures announced by the Government of the Russian Federation in mid-March 2020 to support the housing construction sector and the residential real estate market, Contains special approaches to the application of financial sanctions within the framework of legislation on shared construction for disrupting the deadlines for the fulfillment of obligations by developers in housing construction in 2020, In addition, a temporary moratorium on recovery of funds for enforcement proceedings has been introduced, related to the improper fulfillment of obligations by the developer, a temporary ban was established on the inclusion of apartment buildings in the register of problem objects. The list of backbone-forming includes 54 construction organizations that meet such criteria as the volume of construction of residential and non-residential buildings of at least 400.0 thousand square meters. and revenue for 2019 - at least 10 billion rubles. The total volume of facilities under construction among the listed organizations is 53.5 million square meters.

Analyzing the data of the Federal State Statistics Service, expert assessments published in the media, the main measures taken by the Russian Government in the current situation, the existing and potential economic consequences of the pandemic on the Russian economic system, authors, given the experience of emerging from the crises of 1998, 2008 and 2014, attempted to predict the availability of housing for the average Russian citizen in the postpandemic period, since it is the potential of the population to purchase housing that is one of the main catalysts for the condition of the residential real estate market.

\subsection{Forecast of residential real estate market development using the housing availability factor model (including mortgage support)}

Affordability of housing is an indicator of the solvency of the population in the market. The measure of housing affordability determines how close a buyer is to buying a home and is one of the indicators that can predict the situation in the residential real estate market. To analyze the change in housing affordability in the post-pandemic period, the authors used an improved mathematical model of housing affordability, taking into account mortgage support [34, 35], which is as follows:

$$
-\left[\begin{array}{l}
K_{d}\left(S, P, I, \propto_{p v}, \beta_{g s}, V_{u}, V_{d}, P M T\right)=\frac{S * P *\left(\propto_{p v}-\beta_{g s}\right)-V_{U}+V_{d}}{(I-P M)}, \\
\text { at } I>\left(P M+12 P M T\left(B_{0}, n, i-v_{g s}\right)\right), \text { aka } K_{d}>\infty,
\end{array}\right.
$$

$S \quad$ - is the total area of the apartment,

$P \quad$ - average price per 1 square metre of housing,

$\alpha_{p v}$ - the share of the down payment in the cost of housing,

$\beta_{g s}$ - the share of the cost of housing subsidized by the State,

$P M$ - the value of the current annual expenses of the family, 
$V_{u}$ - the cost of existing housing, counted at the issuance of a loan,

$V_{d}$ - additional costs of the borrower in obtaining a loan,

$n$ - crediting period in years,

$j \quad-$ is the annual interest rate of the loan,

$v_{g s}$ - number of points of interest rate subsidized by the state,

$I \quad$ - is the total annual income of the family,

$P M T$ - is the monthly payment amount of the loan.

The economic meaning of method (1) is that a family that has accumulated a certain amount of funds (a share) for the purchase of an apartment, through a mortgage loan, immediately receives it into ownership. The economic meaning of condition (2) is that the borrower may lose the opportunity to purchase an apartment or lose his acquired apartment if his current income is less than the amount of current expenses and annual payments on the loan. In this case, the condition of housing affordability is not met, the coefficient of accessibility tends to infinity.

When building the model, data were used from a survey of the All-Russian Center for the Study of Public Opinion [27], according to which the average mortgage borrower in 2019 is a person of 33 years old who has a higher education and is a specialist or middle manager with a salary of 40-50 thousand rubles per month.

On the basis of the above formulas, the housing affordability ratio was calculated on the basis of the following conditions:

1 option (pessimistic forecast), provided that in the second half of 2020 the dynamics of socio-economic processes, which was observed in the first half of this year, will continue.

2 option (optimistic forecast), provided that in the second half of 2020 the state mortgage subsidy program, state support for citizens and businesses, support for the growth rate of the average price of residential real estate at the inflation level and the loan provision period will be increased from 18 years to 30 years.

Table 2 shows the data used by the authors to construct a model for the first and second scenarios.

Table 2. Data for calculating the housing affordability coefficient, thousand rubles.

\begin{tabular}{|c|c|c|c|c|c|c|c|}
\hline Indicator & $\begin{array}{c}\mathbf{0 1 . 0 1 .} \\
\mathbf{2 0 1 8}\end{array}$ & $\begin{array}{c}\mathbf{0 1 . 0 1} \\
\mathbf{2 0 1 9}\end{array}$ & $\begin{array}{c}\mathbf{0 1 . 0 1 .} \\
\mathbf{2 0 2 0}\end{array}$ & $\begin{array}{c}\mathbf{0 1 . 0 4} \\
\mathbf{2 0 2 0}\end{array}$ & $\begin{array}{c}\mathbf{0 1 . 0 7 .} \\
\mathbf{2 0 2 0}\end{array}$ & $\begin{array}{c}\mathbf{2 0 2 1} \\
\text { (pessimistic } \\
\text { forecast) }\end{array}$ & $\begin{array}{c}\mathbf{0 1 . 0 1 .} \\
\mathbf{2 0 2 1} \\
\text { (optimi } \\
\text { ftic } \\
\text { forecast } \\
\text { ) }\end{array}$ \\
\hline $\begin{array}{c}\text { Average amount } \\
\text { of credit granted }\end{array}$ & 2238,8 & 2233,3 & 2297,8 & 3051,0 & 3240,2 & 3564,2 & 3 \\
\hline $\begin{array}{c}\text { The average price } \\
\text { for 1 sq.m of } \\
\text { housing }\end{array}$ & 41,5 & 41,4 & 42,6 & 56,5 & 60,0 & 66,0 & 61,2 \\
\hline $\begin{array}{c}\text { Loan term in years } \\
\begin{array}{c}\text { Weighted average } \\
\text { rate on loans } \\
\text { issued during the } \\
\text { month, } \%\end{array}\end{array}$ & 16 & 17 & 18 & 18 & 18 & 18 & 30 \\
\hline $\begin{array}{c}\text { Total annual } \\
\text { family income }\end{array}$ & 1348,9 & 1403,0 & 1489,9 & 334,4 & 347,1 & 1226,7 & 1499,3 \\
\hline $\begin{array}{c}\text { The amount of the } \\
\text { family's current } \\
\text { annual expenses }\end{array}$ & 1079,1 & 1122,4 & 1191,9 & 267,5 & 277,7 & 981,4 & 1199,5 \\
\hline $\begin{array}{c}\text { The total annual } \\
\text { expenses of the } \\
\text { family }\end{array}$ & 1343,6 & 1389,3 & 1461,6 & 540,9 & 518,2 & 1262,5 & 1453,1 \\
\hline
\end{tabular}


Table 2. Continued.

\begin{tabular}{|c|c|c|c|c|c|c|c|}
\hline $\begin{array}{c}\text { Share of the initial } \\
\text { payment in the } \\
\text { price of the } \\
\text { apartment }\end{array}$ & 0 & 0 & 0 & 0 & 0 & 0 & 0 \\
\hline Indicator & $\begin{array}{c}\mathbf{0 1 . 0 1 .} \\
\mathbf{2 0 1 8}\end{array}$ & $\begin{array}{c}\mathbf{0 1 . 0 1} \\
\mathbf{2 0 1 9}\end{array}$ & $\begin{array}{c}\mathbf{0 1 . 0 1} \\
\mathbf{2 0 2 0}\end{array}$ & $\begin{array}{c}\mathbf{0 1 . 0 4} . \\
\mathbf{2 0 2 0}\end{array}$ & $\begin{array}{c}\mathbf{0 1 . 0 7} \\
\mathbf{2 0 2 0}\end{array}$ & $\begin{array}{c}\mathbf{0 1 . 0 1 .} \\
\mathbf{2 0 2 1} \\
\text { (pessimistic } \\
\text { forecast) }\end{array}$ & $\begin{array}{c}\mathbf{0 1 . 0 1} \\
\mathbf{2 0 2 1} \\
\text { optimi } \\
\text { stic } \\
\text { forecast } \\
\text { ) }\end{array}$ \\
\hline $\begin{array}{c}\text { Apartment size, sq } \\
\text { m }\end{array}$ & 54 & 54 & 54 & 54 & 54 & 54 & 54 \\
\hline $\begin{array}{c}\text { The amount of the } \\
\text { annual payment } \\
\text { for a loan }\end{array}$ & 264,5 & 266,9 & 269,7 & 273,4 & 240,5 & 281,1 & 253,7 \\
\hline $\begin{array}{c}\text { The housing } \\
\text { affordability ratio }\end{array}$ & 42,02 & 16,26 & 8,12 & $\mathrm{x}$ & $\mathrm{x}$ & $\rightarrow \infty$ & 7,15 \\
\hline
\end{tabular}

When building the model, data from a survey of the All-Russian Center for the Study of Public Opinion were also used, according to which the average mortgage borrower in 2019 is a person of 33 years old who has a higher education and is a specialist or middle manager with a salary of 40-50 thousand rubles per month. The mortgage borrower's family has one or two children. The total income of the family is $70-80$ thousand rubles per month [27].

The graph (Fig. 9) shows the result of the calculation of the housing availability coefficient in Russia and its forecast for the short term in the postpandemic period.

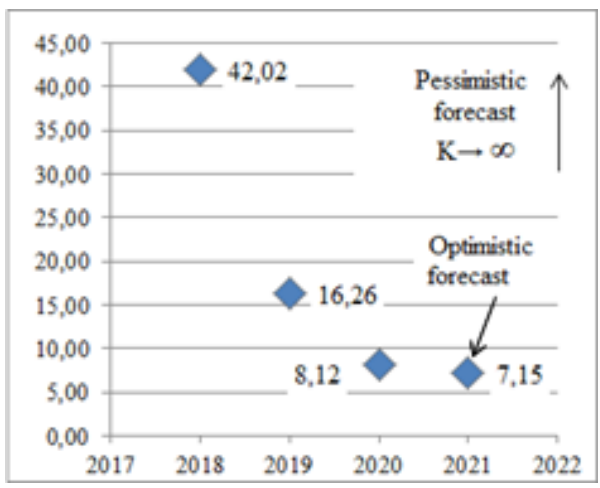

Fig. 9. The result of the calculation of the housing availability coefficient in Russia and its forecast for the short term in the postpandemic period.

Demand in the domestic real estate market is characterized by a high sensitivity to mortgage rates. However, a significant deterioration in the solvency of the population in the first half of 2020 (due to ongoing reductions in the labor market, lower wages, depreciation of savings, etc., which we have discussed above) reduces the consumer's sensitivity to mortgage conditions: even with a lower credit burden, the buyer cannot afford to buy housing in the new economic conditions. In April 2020, despite a 2.2 pp reduction in the mortgage rate compared to April 2019 (facilitated by the Bank of Russia's consistent monetary policy to reduce the key rate and the implementation of a preferential mortgage program at a rate of $6.5 \%$ ), the number of mortgages decreased by $17 \%$ in the housing market as a whole. In the primary market, the number of mortgages in April 2020 decreased even more $(-31 \%)$ with a decrease in the mortgage rate by 3.2 percentage points. According to a survey by the Center for Socio-Economic Research for most Russians (59\%), who have a need to buy housing, the key condition for this is to improve the material situation and only for $5 \%$ - to reduce mortgage rates. 
According to experts of the Center for Socio-Economic Research (taking into account the identified "crisis" features when making decisions of Russians on the purchase of housing in response to lower interest rates), the effect directly from the preferential program may amount to 70 billion rubles or $8 \%$ of the issued volume in 2019 (this is the amount by which mortgage lending will increase thanks to citizens who made a positive decision to buy housing due to the availability of a preferential rate). It is important that the effect has greater potential when the conditions are prolonged. Based on the conclusions made by experts, as well as the calculations made by the authors, it seems advisable, along with an increase in the volume of the mortgage loan to 6 and 12 million rubles. extend the implementation period of the preferential mortgage program for the period 2021-2022 until the restoration of citizens' incomes after the "shock" events of 2020, increase the term of mortgage lending to 30 years, as well as support programs for certain categories of citizens. The adoption of these measures, as follows from the calculation of the housing affordability coefficient according to the optimistic option, will allow the residential real estate market to return to the pre-crisis state in 2021.

\section{Conclusions}

Given that on the eve of the crisis of 2008, the domestic economic system was in a state of economic recovery, and the period preceding the COVID-19 is characterized as a period of economic stagnation, accompanied by a drop in real incomes of the population and its lending, the restoration of the residential real estate market will be protracted. It is predicted that during the current year and the beginning of 2021, the growth rate of the average price of residential real estate will be ahead of inflation. In the second half of the year, most likely, the market will stabilize, the growth rate of the average price of residential real estate will be approximately at the level of inflation.

The more active role of state support for the residential real estate construction sector in the form of subsidizing the interest rate on mortgages (prolonging the mortgage subsidy program with an even lower rate, increasing the credit limit), developing support programs for certain categories of citizens, compensating for the costs of epidemiological measures will have a positive impact on the recovery process of the residential real estate market.

The increase in real incomes of the population in 2020, as well as the implementation of state support measures, can significantly increase the availability of housing (including with the participation of mortgage loans), contributing to the growth of the residential real estate market.

However, with the spread of coronavirus and uncertainty about the dynamics of income on the horizon of the coming months, the consumer model of the population can be temporarily adjusted in favor of increasing the share of consumption of essential goods. This, in turn, can have a negative impact on housing demand.

\section{Acknowledgements}

This research would not be able to achieve without a support from of A. U. Albekov and G. M. Sternik.

\section{References}

1. Communication Center of the Government of the Russian Federation on the situation with coronavirus, The measures of the government (2020) https://стопкоронавирус.рф 
2. Federal Service of State Registration, Cadastre and Cartography, Federal database of real estate objects (2020) https://rosreestr.gov.ru/

3. Decree of the President of the Russian Federation, On measures to ensure the sanitary and epidemiological well - being of the population in the Russian Federation in connec tion with the spread of a new coronavirus infection (COVID - 19) (2020) https://www. garant.ru/

4. SberIndex (2020) https://www.sberindex.ru/

5. G. Wong, J. of Urban Economics, 63, 74 (2008)

6. G. S. Argyroudis, F. M. Siokis, Physica A: Statistical Mechanics and its Applications, 524, 576 (2019)

7. M. Nicola, Z. Alsafi, C. Sohrabi, A. Kerwan, A. Al - Jabir, C. Iosifidis, M. Agha, R. A gha, International J. of Surgery, 78, 185 (2020)

8. S. Gudell, Zillow Economic Research (2020) https://www.zillow.com/

9. A. Razgulin, International J. of Management theory and practice, 1, 117 (2010)

10. N.A. Ushakova, N.M. Khurmatullina, J. of Infrastructure sectors of the economy: problems and development prospects, 9, 134 (2015)

11. V. Busov, Vestnik Universiteta, 7, 159 (2015)

12. K.V. Zaychenko, European science, 6 (7), 33 (2015)

13. D. S. Lemeshko, Economics of education, 1, 162 (2011)

14. E.I. Krylov, V.A. Barfolomeeva, Scientific J. of Actual problems of economics and management, 2, 12 (2015)

15. E. S. Mills, J. of Urban Economics, 51, 198 (2002)

16. C. L. Redfearn, The Economic Impacts of Terrorist Attacks, Land Markets and Terrori sm: Uncovering Perceptions of Risk by Examining Land Price Changes Following 9/11, 152 (2005)

17. S. Hazam, D. Felsenstein, Urban Studies, 44 (13), 2529 (2007)

18. S. Dermisi, J. of Real Estate Portfolio Management, 13 (1), 57 (2007)

19. A. Abadie, S. Dermisi, J. of Urban Economics, 64, 451 (2008)

20. Y. Arbel, D. Ben - Shahar, S. Gabriel, Y. Tobol, Regional Science and Urban Economi cs, 40, 415 (2010)

21. T. Besley, H. Mueller, American Economic Review, 102 (2), 810 (2012)

22. N. Dormady, T. Szelazek, A. Rose, Risk Analysis, 34 (1), 187 (2014)

23. FINAM (2020) https://www.finam.ru/

24. Center for market research, Moscow: HSE, The business climate in construction in the II quarter 2020 year (2020)

25. S. Yu. Glazyev, J. of International Economy, 5, 53 (2020)

26. Federal Law 102-Ф3, On Mortgage (Pledge of Real Estate), System Guarantor of the Russian Federation (1998) http://www.garant.ru/

27. Center for Socio-Economic Research, Construction and real estate market: industry incentives against the backdrop of the crisis - 2020 (2020) https://www.csr.ru/

28. Federal State Statistics Service, Official statistics (2020) https://rosstat.gov.ru/

29. Construction Russia, Falling housing market in crisis years: 1998, 2008, 2014 (2018) https://строй-россия.pф//

30. Bank of Russia, Housing construction, 1(2) (2020) http://www.cbr.ru/ 
31. Bank of Russia, Housing construction, 3 (2019) http://www.cbr.ru/

32. National Support Center for BRICS Investors, Emerging Trends in Real Estate, Europe 2020 (2020) https://ru.investinrussia.com/

33. V.S. Gurevich, S.M. Drobyshevsky, A.V. Kolesnikov, V.A. Mau, S.G. Sinelnikov, Mo nitoring of the economic situation in Russia: trends and challenges of socio - economic development, 18(120) (2020)

34. G.M. Sternik, S.G. Sternik, Analysis of real estate wound for professionals (2009)

35. G.M. Sternik, S.G. Sternik, Methodology for modeling and forecasting the housing market (2018) 